\title{
Study of the diffusion of metals and metals-EDTA complexes in water by capillary method
}

\author{
Zilong Geng ${ }^{1}$, Hui Chen ${ }^{1}$, Chenyu Yang ${ }^{1}$, Qiang Shen ${ }^{1}$, Tao $\mathrm{Wu}^{* 1}$ \\ ${ }^{1}$ Department of Engineering, Huzhou University, 313000 Huzhou, P. R. China
}

\begin{abstract}
EDTA can complex with radionuclides (RNs) to form negatively charged complexes, making it difficult for clay minerals to retard the diffusion of RNs waste. The diffusion coefficient of RNs in water $\left(D_{w}\right)$ is an important parameter for the safety assessment of the repository. In this study, the effectsof EDTA on the diffusion of metal ions $\left(\mathrm{Cu}^{2+}, \mathrm{Sm}^{3+}, \mathrm{Nd}^{3+}, \mathrm{Lu}^{3+}\right.$ and $\left.\mathrm{Zn}^{2+}\right)$ were investigated by a capillary method. The experimental results showed that [Cu-EDTA $]^{2-}$, [Sm-EDTA $]^{-}$and [La-EDTA $]^{-}$have higher $D_{w}$ thanthe $\mathrm{Mn}+$. Whereas, [Nd-EDTA] $]^{-}$and $[\mathrm{Zn}-\mathrm{EDTA}]^{2-}$ have lower $D_{w}$ than $\mathrm{Nd}^{3+}$ and $\mathrm{Zn}^{2+}$ cations. The $D_{w}$ is consistent with the literatures, indicating the validity of the capillary method to determine the diffusion coefficients. According to Stokes-Einstein relation, the ionic radius and ionic potential of the ion are in disproportional to the $D_{w}$ value. Cu-, Sm- and La-EDTA complexes have smaller molecular size than the uncomplexed metal ions, indicating that the $\mathrm{M}^{\mathrm{n}+}$ ions might be associated with many water molecules to form hydrated ions with larger ionic radius. Whereas the $[\mathrm{Nd}-\mathrm{EDTA}]^{-}$and $[\mathrm{Zn}-\mathrm{EDTA}]^{2-}$ have larger molecular size than $\mathrm{Nd}^{3+}$ and $\mathrm{Zn}^{2+}$ cations.
\end{abstract}

\section{Introduction}

Ethylenediaminetetraacetate (EDTA) is often used as a chelate for agricultural and industrial applications, resulting in an increase of EDTA concentrations in various water sources. It may complex with free heavy metal ions to form solublecomplexation, thus enhancing the transportation of $\mathrm{M}-E D T A^{(\mathrm{Z}-4)^{+}}$ complexes in water and clays barrier systems ${ }^{1-3}$. The effect of EDTA on the transportation of metal ions has been attracted a lot of attention, such as ${ }^{85} \mathrm{Sr}-\mathrm{EDTA}^{2-}$ in sediments ${ }^{4}, \mathrm{Cd} / \mathrm{Co}^{-E_{D T A}}{ }^{2-}$ in saprolite ${ }^{5}$, and EuEDTA $^{-}$in hard clay rock ${ }^{6}$. EDTA can decrease the adsorption of metal ions on minerals and enhance their transportation not only due to the formation of negatively charge complexes ${ }^{7,8}$, but also due to the reducing of the clay specific surface area ${ }^{9}$. For example, equimolar EDTA inhibited the sorption of U(VI) on montmorillonite due to the formation of negatively charged $\mathrm{UO}_{2}$ HEDTA $^{-}, \quad\left(\mathrm{UO}_{2}\right)_{2} \mathrm{OHEDTA}^{-}$and $\left(\mathrm{UO}_{2}\right)_{2} \mathrm{EDTA}_{2}{ }^{4-7}$. The transportation of $\mathrm{Th}^{4+}$ through sands was enhanced by EDTA due to the formation of $\mathrm{Th}(\mathrm{OH})(\mathrm{EDTA}){ }_{2}{ }^{2-}$ and $\mathrm{Th}(\mathrm{OH})(\mathrm{EDTA})^{-2}$.

In order to retard the transportation of radionuclidewaste, it often uses porous materials with low permeability such as clay rock and compacted bentonite as backfill material for the repository. Diffusion is the predominant behavior of radionulide ions. Diffusion coefficient of RNs in water $\left(D_{w}\right)$ is one of the most important parameters to predict the diffusion behavior of RNs in backfill material and the surrounding rock. The diffusion cell method is often used in determining the diffusion coefficient of RNs in water ${ }^{1,10}$ and in minerals ${ }^{6,11}$. EDTA can alter diffusion of RNs by complexaion reaction or by the modification of the properties of minerals. Due to the large molceular size of EDTA, the diffusion coefficient of M-EDTA ${ }^{(\mathrm{Z}-4)+}$ complexes in water was found to be similar among various metal ions ${ }^{1}$. Descostes et al. (2017) reported that EDTA increase the diffusion of RNs in clays due to the formation of negatively charged complexes. Anionic exclusion of [Eu-EDTA] $]^{-}$was found in the rock clay. However, to the best of our knowledge, only a few studies related to the effect of EDTA on the diffusion of RNs were reported due to the long experimental period ${ }^{1,6,9}$

Tri-valent lanthanides were often used as the surrogates of tri-valent actinides to avoid the operation of radioactivity experiments. In this study, the effect of EDTA on metals ions $\left(\mathrm{Cu}^{2+}, \mathrm{Sm}^{3+}, \mathrm{Nd}^{3+}, \mathrm{Lu}^{3+}\right.$ and $\left.\mathrm{Zn}^{2+}\right)$ were investigated by a capillary method. The aim is to verifiy this method to the classis conductivity method and diffusion cell method. Some new diffusion coefficients of ions were also provided. We wish to have more knowledge of the diffusion properties of MEDTA $^{(Z-4)+}$ complexes before the diffusion experiment in clay starts.

\footnotetext{
*Corresponding author: twu@zjhu.edu.cn
} 


\section{Materials and Methods}

\subsection{Experiments}

\subsubsection{Materials}

The diffusion experiments were conducted at aerobic condition. Reagent-grade $\mathrm{CuCl}_{2} \cdot \mathrm{H}_{2} \mathrm{O}, \mathrm{SmCl}_{3} \cdot 6 \mathrm{H}_{2} \mathrm{O}$, $\mathrm{LaCl}_{3} \cdot 6 \mathrm{H}_{2} \mathrm{O}, \quad \mathrm{NdCl}_{3} \cdot 6 \mathrm{H}_{2} \mathrm{O}, \quad \mathrm{ZnCl}_{2}, \quad \mathrm{LuCl}_{3} \cdot 6 \mathrm{H}_{2} \mathrm{O}$ (Aaladdin) and ethylenediaminetetraacetic acid disodium salt ( $\mathrm{Na}_{2}$ EDTA, Aaladdin). The solution was prepared in Milli-Q $(18 \mathrm{M} \Omega / \mathrm{cm})$ water.

The aqueous chemical speciation of M-EDTA ${ }^{(Z-4)+}$ complexes were calculated by using HySS (Hyperquad Simulation and Speciation) computer program. The stablity constants from literature were used for calculations ${ }^{12}$. All $\mathrm{M}^{\mathrm{n}+}$ cations was mainly formed with EDTA as soluable M-EDTA ${ }^{(\mathrm{Z}-4)+}$ complexes with almost $100 \%$ in $0.5 \mathrm{M} \mathrm{NaCl}$ solution due to the large stability constantes of M-EDTA ${ }^{(\mathrm{Z}-4)+}$ complexes.

\subsubsection{Diffusion experiment}

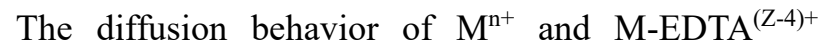
complexes in water will be investigated by a capillary method with single element solution (Fig.1). A working solution of $\mathrm{Cu}^{2+}$ was prepared by dissolving solid metal chlorides in $0.5 \mathrm{M} \mathrm{NaCl}$ solution. $0.1 \mathrm{~mol} / \mathrm{L}$ of $\mathrm{Cu}^{2+}$ stock solution was prepared by adding some $\mathrm{Cu}^{2+}$ working solution in $0.5 \mathrm{~mol} / \mathrm{L}$ of $\mathrm{NaCl}$ solution. The $\mathrm{pH}$ was adjusted to $7.0 \pm 0.2$ by adding minor $\mathrm{HCl}$ or $\mathrm{NaOH}$. The $5.0 \mathrm{ml}$ vials were filled with $4.0 \mathrm{ml}$ of tracer free $\mathrm{NaCl}$ solution. After a capillary was fit into an opening in the cap of the vial, the glass open-ended capillary (diameter ca. $0.85 \mathrm{~mm}$ ) was filled with $25 \mu \mathrm{L} \mathrm{Cu}^{2+}$ at a length of ca. $4.7 \mathrm{~cm}$, and then a parafilm membrane sealed the upper end of the capillary. The bottom end of the capillary immerged into $0.5 \mathrm{~mol} / \mathrm{L}$ of $\mathrm{NaCl}$ solution (Fig. 1A). The out-diffusion of $\mathrm{Cu}^{2+}$ from the capillary into the solution started. After a certain time interval, the capillary was removed from the solution. The concentration of copper in vials was measured by an inductively coupled plasma-optical emission spectrometer (ICP-OES, Perkin Elmer, Optima 7000 DV). The same experimental procedures were conducted for the other metal ions $\left(\mathrm{Sm}^{3+}, \mathrm{La}^{3+}, \mathrm{Nd}^{3+}\right.$, $\mathrm{Zn}^{3+}$ and $\mathrm{Lu}^{3+}$ ) and M-EDTA ${ }^{(\mathrm{Z}-4)+}$ complexes.

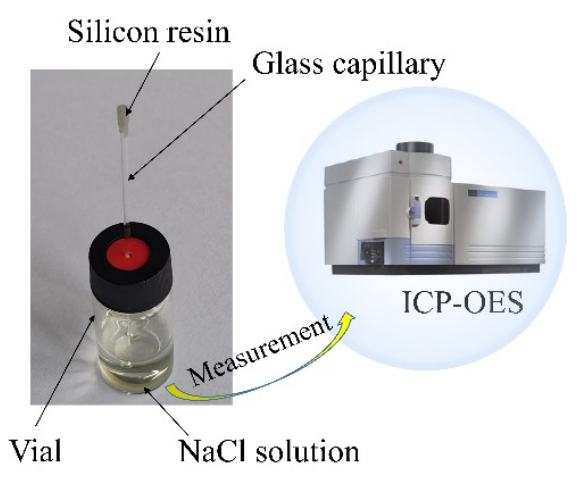

Fig.1 The diffusion set-up for the capillary method.

\subsection{Computational methods}

\subsubsection{Determination of the diffusion coefficients of free metal ions}

The diffusion coefficient $\left(D_{w}\right)$ for a metal ion in $\mathrm{NaCl}$ solution was obtained by fitting the concentration of the metal ion in vials as a function of time by the following equation ${ }^{13}$ :

$\frac{C}{C_{0}}=\frac{8}{\pi^{2}} \sum_{n=0}^{\infty} \frac{1}{(2 n+1)^{2}} \exp \left[-(2 n+1)^{2} \cdot \pi^{2} \cdot D_{w} \cdot t / 4 L^{2}\right](1)$

where $C(\mathrm{~mol} / \mathrm{L})$ is the concentration of the metal ion in the vials. $\mathrm{C}_{0}(\mathrm{~mol} / \mathrm{L})$ is the initial concentration of the metal ion. $L(\mathrm{~m})$ is the filled length of metal ions solution in the capillary. It was $0.047 \mathrm{~m}$ in this study.

$D_{w}$ is related to the diffusion coefficients of $\mathrm{M}^{\mathrm{n}+}$ and M-EDTA ${ }^{(\mathrm{Z}-4)^{+}}$complexes $\left(D_{w, 0}\right)$ and $\mathrm{NaCl}$ ion $\left(D_{w, e}\right)$ in diluted solution as follows ${ }^{14}$ :

$D_{w}=\frac{Z_{1}^{2} c_{1}+Z_{2}^{2} c_{2}}{Z_{1}^{2} c_{1} / D_{w, e}+Z_{2}^{2} c_{2} / D_{w, 0}}$

where $D_{w, N a+}$ is $1.33 \times 10^{-9} \mathrm{~m}^{2} / \mathrm{s}^{14}$.

\subsubsection{Calculation of ionic radius of $\mathrm{M}^{\mathrm{n}+}$ and $\mathrm{M}$ - EDTA $^{(z-4)+}$ complexes}

The ionic radius of the diffusing species $(r, \AA)$ is calculated by the classic Stokes-Einstein relation as follows:

$r=\frac{k T}{6 \pi \eta D_{w}}$

where $k\left(1.380649 \times 10^{-23} \mathrm{~Pa} \cdot \mathrm{m}^{3} / \mathrm{K}\right)$ is the Boltzmann constant, $T(\mathrm{~K})$ is the temperature and $\eta(\mathrm{Pa} \cdot \mathrm{s})$ is the viscosity of the medium, which is $0.9365 \times 10^{-3} \mathrm{~Pa} \cdot \mathrm{s}$ in $0.5 \mathrm{~mol} / \mathrm{L}$ of $\mathrm{NaCl}$ solution ${ }^{15}$.

The ionic potential $\left(I_{p}\right)$ is defined as:

$I_{p}=|z| / r$

where $z$ is the charge of ion and $r$ is the ionic radius $(\AA)$. 


\section{Results \& Discussion}

Fig. 2 shows the diffusion profile of $\mathrm{M}^{\mathrm{n}+}$ and $\mathrm{M}-$ EDTA $^{(\mathrm{Z}-4)+}$ complexes in $0.5 \mathrm{M} \mathrm{NaCl}$ solution. Due to the large stability constants of M-EDTA ${ }^{(\mathrm{Z}-4)+}$ complexes, almost $100 \%$ complexes were formed in $0.5 \mathrm{M} \mathrm{NaCl}$ solution. The concentration ratio of $\mathrm{M}^{\mathrm{n}+}$ and $\mathrm{M}$ EDTA $^{(\mathrm{Z}-4)+}$ complexes increased with increasing time. The concentration ratio of $\mathrm{M}-\mathrm{EDTA}^{(\mathrm{Z}-4)+}\left(\mathrm{M}=\mathrm{Cu}^{2+}\right.$, $\mathrm{Sm}^{3+}$ and $\mathrm{La}^{3+}$ ) complexes are higher than that of $\mathrm{M}^{\mathrm{n}+}$, indicating that the complexes diffuse faster than the metal ions. Whereas, the ratio of $\mathrm{M}-\mathrm{EDTA}^{(\mathrm{Z}-4)+}(\mathrm{M}=$ $\mathrm{Nd}^{3+}$ and $\mathrm{Zn}^{2+}$ ) complexes are lower than that of $\mathrm{M}^{\mathrm{n}+}$, implying a higher diffusion velocity of metal ions than that of the complexes.

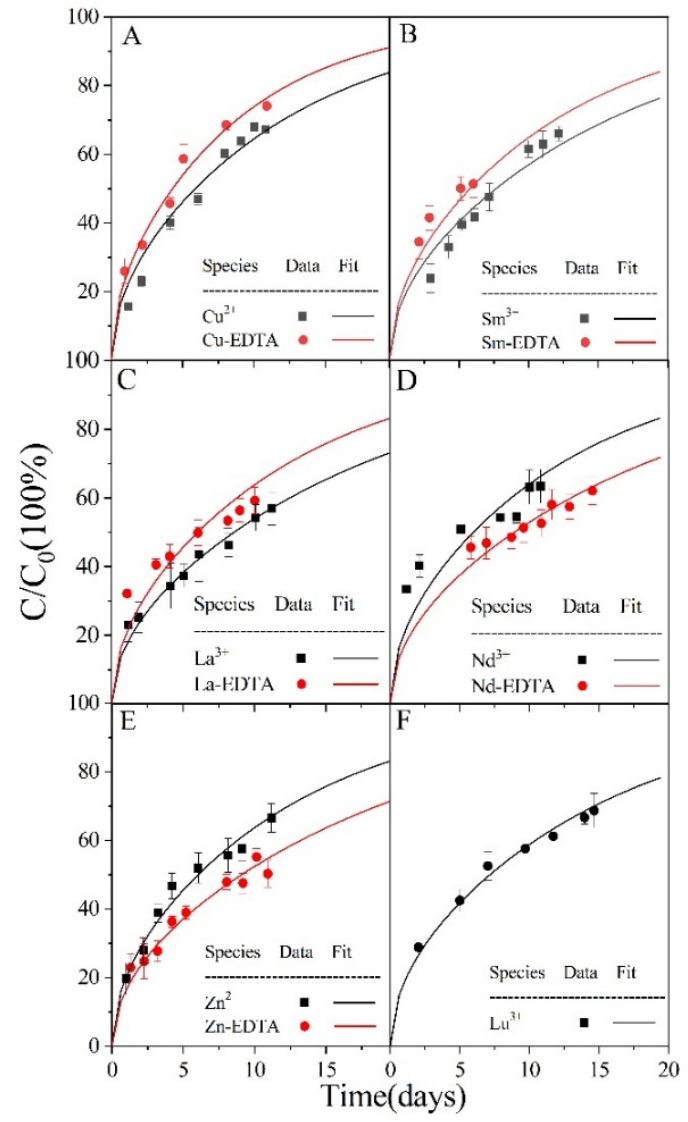

Fig.2 The diffusion profile of $\mathrm{M}^{\mathrm{n}+}$ and M-EDTA ${ }^{(\mathrm{Z}-4)+}$ complexes in $0.5 \mathrm{M} \mathrm{NaCl}$ solution. $\mathrm{T}=20{ }^{\circ} \mathrm{C}, \mathrm{C}_{0}\left(\mathrm{M}^{\mathrm{n}+}\right)=1.0 \times 10^{-3} \mathrm{~mol} / \mathrm{L}$.
The diffusion coefficients, the ionic radii and the

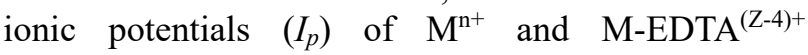
complexes were summerized in Table 1 . The results were compared with the $D_{w}$ measuremed by diffusion cell method and the limiting molar ionic conductivites using the Nernst-Einstein equation 1, 10, 14, 16. The diffusion coefficient was obtained by fitting the experimental data as shown in Fig.1 by Eq.(1). The ionic radius was calculated by Eq.(3) in this work and for the literatures. $I_{p}$ was calculated by Eq.(4). The $I_{p}$ from literatures are listed in the round bracket in Table 1. The diffusion coefficients of $\mathbf{M}^{\mathrm{n}+}$ ions in diluted water are calculated by Eq.(2), which are consistent with the $D_{w}$ from literatures, indicating the validity of the capillary method to determine the diffusion coefficients. However, the $D_{w}$ of M-EDTA ${ }^{(\mathrm{Z}-4)^{+}}$ complexes were higher in this work than in literature. Since multi-element solution was employed to determine the diffusion coefficient by diffusion cell method as reported by Furukawa et al. (2007), the descrepancy could be explained by the cocomplexation reaction of ions and EDTA.

According to Stokes-Einstein relation as shown in Eq.(1), the diffusion coefficient of ion is in dispropotional to the ionic radius. For $\mathrm{Cu}^{2+}, \mathrm{Sm}^{3+}$ and $\mathrm{La}^{3+}$, the ionic radius of $\mathrm{M}-\mathrm{EDTA}^{(\mathrm{Z}-4)+}$ complexes are smaller than that of $\mathrm{M}^{\mathrm{n}+}$, indicating that the $\mathrm{M}^{\mathrm{n}+}$ ions might be associated with many water molecules to form hydrated ions with larger ionic radius. Whereas, the ionic radius of [Nd-EDTA $]^{-}$and [Zn-EDTA $]^{-}$are larger than that of $\mathrm{Nd}^{3+}$ and $\mathrm{Zn}^{2+}$. The $D_{w}$ of [Nd-EDTA] $]^{-}$and [Zn-EDTA] $]^{-}$are in good agreement with that of Furukawa, et al. (2008), who reported that the $D_{w}$ of Ln$\mathrm{EDTA}^{(\mathrm{Z}-4)+}$ complexes were in the range of $5.43 \times 10^{-10}$ $-5.76 \times 10^{-10} \mathrm{~m}^{2} / \mathrm{s}$, which is close to that of $\mathrm{H}_{2} \mathrm{EDTA}^{2-}$. Since the molceular size of EDTA is much larger tha thato fo metal ions, the diffusion of metal ions lose their characteristics by the complexation. However, the diffusion coefficient of [Cu-EDTA $]^{2-}$, [Sm-EDTA $^{-}$and [La-EDTA] ${ }^{-}$were higher. More experiments will be conducted to clarifed the descrepancy of the diffusion coefficient due to the multi-element solution and single element solution.

Table 1 The diffusion coefficients and molecular radii and of $\mathrm{M}^{\mathrm{n}+}$ and $\mathrm{M}-\mathrm{EDTA}^{(\mathrm{Z}-4)+}$ complexes in $0.5 \mathrm{M} \mathrm{NaCl}$ solution. $\mathrm{T}=20^{\circ} \mathrm{C}$, $\mathrm{C}_{0}\left(\mathrm{M}^{\mathrm{n}+}\right)=1.0 \times 10^{-3} \mathrm{~mol} / \mathrm{L}$

\begin{tabular}{ccccccc}
\hline Species & $D_{w}\left(\times 10^{-10} \mathrm{~m}^{2} / \mathrm{s}\right)$ & $\mathrm{RSD} \%$ & $D_{w, 0}\left(\times 10^{-10} \mathrm{~m}^{2} / \mathrm{s}\right)$ & $r(\AA)$ & $I_{p}$ & Reference \\
\hline $\mathrm{Cu}^{2+}$ & 7.88 & 5.24 & 7.84 & 2.91 & $0.69\left(2.74^{*}\right)$ & This work \\
$\mathrm{Cu}^{2+}$ & & & 7.14 & 3.21 & $0.62(2.95)$ & Li, et al. $(1974)$ \\
$\mathrm{Cu}^{2+}$ & & & 7.33 & 3.13 & 0.64 & Vanysek (2000) \\
$\mathrm{Sm}^{3+}$ & \multirow{3}{*}{6.57} & 5.47 & 6.53 & 3.49 & 0.86 & This work \\
$\mathrm{Sm}^{3+}$ & & & 6.08 & 3.77 & 0.80 & Vanysek (2000) \\
$\mathrm{La}^{3+}$ & 5.87 & 5.43 & 5.84 & 3.90 & $0.77\left(2.78^{*}\right)$ & This work \\
$\mathrm{La}^{3+}$ & & & 6.19 & 3.70 & $0.81(2.47)$ & Vanysek (2000) \\
$\mathrm{Nd}^{3+}$ & 7.39 & 5.44 & 7.35 & 3.10 & 0.97 & This work \\
\hline
\end{tabular}




\begin{tabular}{|c|c|c|c|c|c|c|}
\hline $\mathrm{Nd}^{3+}$ & & & 6.16 & 3.72 & 0.81 & Vanysek (2000) \\
\hline $\mathrm{La}^{3+}$ & & & 6.17 & 3.71 & 0.81 & Li, et al. (1974) \\
\hline $\mathrm{Zn}^{2+}$ & 8.34 & 5.46 & 8.3 & 2.75 & $0.73\left(2.70^{*}\right)$ & This work \\
\hline $\mathrm{Zn}^{2+}$ & & & 8.85 & 2.68 & 0.75 & Li, et al. (1974) \\
\hline $\mathrm{Zn}^{2+}$ & & & 7.03 & 3.26 & 0.61 & Vanysek (2000) \\
\hline $\mathrm{Lu}^{3+}$ & 7.03 & 5.44 & 6.99 & 3.26 & 0.92 & This work \\
\hline $\mathrm{Lu}^{3+}$ & & & 5.9 & 3.88 & 0.77 & Furukawa (2008) \\
\hline$[\mathrm{Cu}-\mathrm{EDTA}]^{2-}$ & 11.7 & 5.47 & 11.7 & 1.77 & 1.13 & This work \\
\hline$[\mathrm{Sm}-\mathrm{EDTA}]^{-}$ & 8.16 & 5.51 & 8.1 & 2.54 & 0.39 & This work \\
\hline$[\mathrm{Sm}-\mathrm{EDTA}]^{-}$ & & 4.50 & 5.53 & 3.75 & $0.27(1.6)$ & Furukawa (2007) \\
\hline 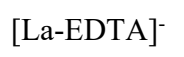 & 8.35 & 5.58 & 8.29 & 2.48 & 0.40 & This work \\
\hline$[\text { La-EDTA] }]^{-}$ & & & 5.47 & 3.79 & $0.26(1.6)$ & Furukawa (2007) \\
\hline [Nd-EDTA $^{-}$ & 5.63 & 5.44 & 5.57 & 3.68 & 0.27 & This work \\
\hline$[\mathrm{Nd}-\mathrm{EDTA}]^{-}$ & & & 5.53 & 3.75 & 0.27 & Furukawa (2007) \\
\hline$[\mathrm{Zn}-\mathrm{EDTA}]^{2-}$ & 5.54 & 5.56 & 5.48 & 3.74 & 0.53 & This work \\
\hline
\end{tabular}

* Data from Nordstrom (1997)

Fig. 3 shows the diffusion coefficients of $\mathrm{M}^{\mathrm{n}+}$ and $\mathrm{M}$ EDTA $^{(\mathrm{Z}-4)^{+}}$complexes as a function of ionic potentials. It is defined as $z / r$, where $z$ is the charge of ion and $r$ is the ionic radius $(\AA)$. It shows a linear relationsip between the diffusion coefficients and ionic potentials. The intercepts decrease with increasing the charge of ions. The ionic potentials of are lower than 1.2, which is inaccordance with the anions reported by $\mathrm{Li}$ and Gergory (1974). However, cations have the lower ionic potentials in this work than in literatures ${ }^{1,10,16}$. It can be explained that the ionic radii of $\mathrm{M}^{\mathrm{n}+}$ ions are larger due to the formation with water molecules to form hydrated ions in this work. The $I_{p}$ is in proprtional to the $D_{w}$ when combined Eq.(2) and Eq. (3), indicating that the ions with high ionic potentials diffuse faster in the water.

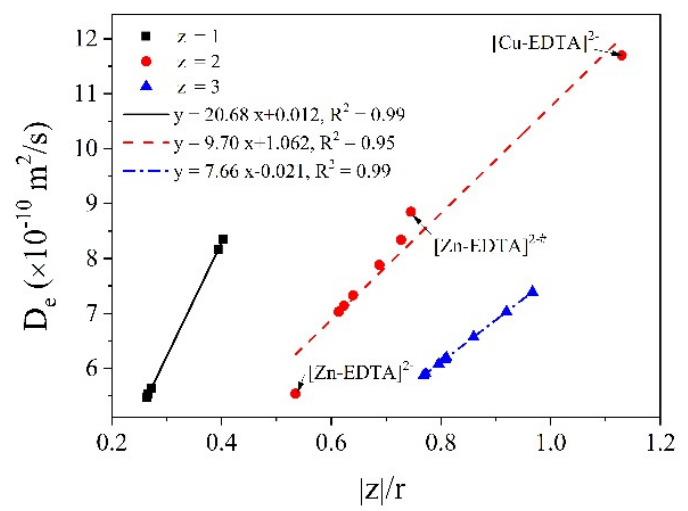

Fig.3 The diffusion coefficients of $\mathrm{M}^{\mathrm{n}+}$ and M-EDTA ${ }^{(\mathrm{Z}-4)+}$ complexes in $0.5 \mathrm{M} \mathrm{NaCl}$ solution as a function of ionic potentials.

\section{Conclusions}

The results of this work indicate that EDTA can alter the diffusion behavior of the metal ions. The diffusion coefficients of ions is in disappropotional to the molecular size and ionic potential of metal ions. The ions with smaller molecular sizes and ionic potentials have higher diffuion ability. Most of M-EDTA ${ }^{(\mathrm{Z}-4)^{+}}$ complexes have similar diffusion velocities with the $D_{w}$ values of $\sim 5.5 \times 10^{-10} \mathrm{~m}^{2} / \mathrm{s}$. Due to the heterogeneity of RNs, the M-EDTA ${ }^{(\mathrm{Z}-4)+}$ complexes do not show similar diffusion behavior. This work provides a simple method to determine the diffusion coefficients of RNs.

\section{Acknowledgments}

This study was supported by National Science Foundation of Zhejiang Province (LY18B070006 and LQ20E040001). We would like to thank Ms. Yudie Wang and Ms. Jiatong Zhao their help for checking the diffusion experimental results.

\section{References}

1 K. Furukawa, Y. Takahashi, H. Sato, Geochimica et Cosmochimica Acta 2007, 71, 4416-4424 https://doi.org/10.1016/j.gca.2007.07.009.

2 C. C. May, L. Young, P. J. Worsfold, S. Heath, N. D. Bryan, M. J. Keith-Roach, Water Research 2012, 46, 4870-4882.

3 E. Reinoso-Maset, P. J. Worsfold, M. J. Keith-Roach, Environmental Pollution 2012, 162, 399-405 https://doi.org/10.1016/j.envpol.2011.11.038.

4 M. N. Pace, M. A. Mayes, P. M. Jardine, L. D. Mckay, X. L. Yin, T. L. Mehlhorn, Q. Liu, H. Guerleyuek, Journal of Contaminant Hydrology 2007, 91, 267-287.

5 M. A. Mayes, P. M. Jardine, I. L. Larsen, S. C. Brooks, S. E. Fendorf, Journal of Contaminant Hydrology 2000, 45, 243-265.

6 M. Descostes, I. Pointeau, J. Radwan, J. Poonoosamy, J.-L. Lacour, D. Menut, T. Vercouter, R. V. H. Dagnelie, Journal of Hydrology 2017, 544, 125-132 https://doi.org/10.1016/j.jhydrol.2016.11.014.

7 W. Q. Zhou, J. Y. Wang, J. G. He, X. Y. Yang, Y. L. 
Shi, X. Y. Wang, C. L. Liu, Colloids and Surfaces aPhysicochemical and Engineering Aspects 2019, 583.

8 D. Read, D. Ross, R. J. Sims, Journal of Contaminant Hydrology 1998, 35, 235-248 https://doi.org/10.1016/S0169-7722(98)00136-3.

9 X. J. You, S. G. Liu, C. M. Dai, G. H. Zhong, Y. P. Duan, Y. J. Tu, Science of the Total Environment 2020, 706.

10 K. Furukawa, Y. Takahashi, Chemosphere 2008, 73, 1272-1278 https://doi.org/10.1016/j.chemosphere.2008.07.017.

11 R. V. H. Dagnelie, P. Arnoux, J. Radwan, D. Lebeau, P. Nerfie, C. Beaucaire, Applied Clay Science 2015, 105, 142-149 10.1016/j.clay.2014.12.004.
12 M. Zabiszak, M. Nowak, K. Taras-Goslinska, M. T. Kaczmarek, Z. Hnatejko, R. Jastrzab, Journal of Inorganic Biochemistry 2018, 182, 37-47 https://doi.org/10.1016/j.jinorgbio.2018.01.017.

13 T. Wu, S. Amayri, J. Drebert, L. R. Van Loon, T. Reich, Environmental Science \& Technology 2009, 43, 6567-6571.

14 P. Vanysek, CRC Handbook of Chemistry and Physics 2000, 83, 76-78.

15 F. ., A., Gonalves, J., Kestin, Berichte der Bunsengesellschaft für physikalische Chemie 1977, 81, 1156-1161.

16 Y. H. Li, S. Gregory, Geochimica et Cosmochimica Acta 1974, 38, 703-714 https://doi.org/10.1016/0016-7037(74)90145-8. 